\title{
THE STATUS OF A DEFENDANT IN EQUITY TO A BILL FOR INFRINGEMENT OF LETTERS PATENT.
}

By John K. Beach, of the New Haven Bar.

The title will be considered especially with reference to the grounds upon which equity requires an infringer to account for and pay over to the complainant the gains and profits of the infringing business.

Nothing, of course, can be added to the scholarly analysis of the grounds of equity jurisdiction in patent causes made by $\mathrm{Mr}$. Justice Matthews in the decision of Root $v$. Railway, but it is to be feared that the distinction which is there drawn, between the position of a real trustee, accounting for his use of another's property, and the position of an ordinary defendant, converted by a device of equity into a fictitious trustee; accounting for his profits for the purpose of giving to the complainant some substitute for damages arising from the tort, is too fine for every-day use.

In Root $v$. Railway, which was in effect a revision and explanation of all the preceding cases bearing on the status of infringers in courts of equity, the precise question at issue was whether an infringer of a patent was a trustee of his gains and profits and liable to account in equity as such trustee; and the precise point decided was that the infringer was not liable to account as a trustee, but that, equity having taken jurisdiction for another purpose, would proceed to apply to an infringer the rule adopted in cases of trustees who have misappropriated trust funds, and would compel the infringer to refund the profit actually realized.

That is to say, he is not a trustee, but is nevertheless within certain limits treated as a trustee.

Among other patent causes cited by Mr. Justice Matthews as foreshadowing the doctrine that an infringer was not a trustee, is that of Goodyear $v$. Rubber Co., a case in which over three hundred thousand dollärs of defendant's profits were awarded to the complainant, and the rule of ascertaining such profits was carefully stated in the following language :

"The profits made in violation of the rights of the complainants in this class of cases, within the meaning of the law, are to be computed and ascertained by finding the difference between cost and yield. In estimating the 
cost, the elements of price of materials, interest, expenses of manufacture and sale, and other necessary expenditures, if any there be, and bad debts, are to be taken into the account, and usually nothing else. The calculation is to be made as a manufacturer calculates the profits of his business. 'Profit' is the gain made upon any business or investment when both the receipts and payments are taken into the account."

The correctness of this rule, which, it will be observed, is exactly in line with the doctrine of Root $v$. Railway, has never been openly questioned by the Supreme Court since it was announced. In Callaghan $v$. Myers, I28 U. S., a copyright case, there may be traced a disposition to treat an infringer as if he were really a trustee, or a converter of property belonging to the complainant, but there is no suggestion that Root $v$. Railway and Goodyear v. Rubber Co. are not good law.

But in the more recent case of Crosby Valve Co. $v$. Safety Valve Co., I4I U. S., the court has laid down a rule for the ascertainment of defendant's profits which is in direct conflict with the Goodyear case, and is logically at variance with Root $v$. Railway.

In Crosby Valve Co. v. Safety Valve Co., the defendant had sold some infringing valves at ascertained profit, but claimed the right to set off in reduction of that profit, a loss incurred in the manufacture of certain infringing valves which turned out to be imperfect and were destroyed. As to this claim the court said:

"As for the contention that the destroyed valves ought to form a credit against the profits actually realized by the defendants on the valves. it is sufficient to say that the only enquiry is the profit made by the defendant on the articles which it sold at a profit and for which it received payment, and that losses incurred by the defendant through its wrongful invasion of the patent are not chargeable to the plaintiff, nor can their amount be deducted from the compensation which the plaintiff is entitled to receive."

Citing the Cawood patent, Elizabeth v. Pavement Co. and Tilghman v. Proctor.

There may be a distinction in the calculation of profits between articles destroyed before sale, and articles actually sold at a loss by reason of a bad debt, but the language of the court is wide enough to include all cases where a profit is realized on one sale and a loss on another. For example, if the valves cost five dollars each, and two were sold at a nominal price of eight dollars, and the vendee, after paying for the first, but before paying for the second, failed in business, and his estate paid only twenty-five cents on the dollar; the account would show a profit of three dollars on one sale and a loss of three dollars on the second. According to Goodyear v. Rubber Co., which expressly states that bad debts are to be allowed the defendant, there would be no 
profit, but according to Crosby Valve Co. $v$. Safety Valve Co. there would be a profit of three dollars, to be paid over to the complainant.

There is presented therefore a direct conflict of authority between the rule stated in $\mathrm{x} 8 \mathrm{gr}$ by Mr. Justice Blatchford in the following language :

"The only enquiry is the profit made by the defendant on the articles which it sold at a profit and for which it received payment,"

and the rule stated in 1869 by Mr. Justice Swayne :

"In estimating the cost, the elements of price of materials, interest, expenses of manufacture and sale, and other necessary expenditures, if any there be, and bad debts, are to be taken into the account."

So far as the Supreme Court is concerned, the authorities, as indicated above, are evenly balanced, for the precedents cited by the court in the valve case do not touch the point, and as no reference at all was made to the Goodyear case, it would be unsafe to treat it as overruled.

The Cawood patent, Tilghman $v$. Proctor, and the dictum in Elizabeth $v$. Pavement Co., go no further than to say that where the use of a patented invention has resulted in an ascertained saving to the infringer, he must account for that saving even though the whole result of his business at large was a net loss. In those cases the savings referred to were calculated as the net result of the whole infringement, and there was no suggestion that one disadvantageous infringing act should be set off against another advantageous infringing act of the defendant.

In the Circuit Court, the first appearance of the Valve case doctrine was in Graham v. Mason, 5th Fisher, 290, 1872. That case presented no question of setting off a profitable sale against an unprofitable one, but Judge Shepley nevertheless stated an imaginary case of that sort, and announced his belief that no such right of set-off existed, because such a right would be unjust to the patentee.

This was in flat contradictiou of Goodyear $v$. Rubber Co., and being purely obiter also, the case can hardly be said to be an authority on the point in question. Moreover, Judge Shepley was unfortunate in the grounds on which he based this belief, for he reasons from the assumption that if the patentee had known beforehand exactly what sales had been profitable he might have declared on these alone in his bill, and have ignored the others; but in reality such a bill would be demurrable under Root $v$. Railway, and so the learned Judge's argument might be turned. against himself, if it were worth while. 
There is, however, one case-Steam Stone Cutter Co. $v$. Windron Mfg. Co. (1879), 17 Blatch. 24, in which the doctrine that only profitable sales are to be taken into the account is definitely laid down and applied by Judge Wheeler. The opinion assumes the right of the complainant to follow up each sale separately and take the proceeds thereof without reference to the rest, and illustrates the proposition by saying that the sale of the patented improvement in connection with the defendant's machine "is the same as if anything else belonging to the orator had been put into and sold with the machines, and the orator claimed what that had brought."

In aiming at the conclusion stated, the court makes two assumptions ; first that a patentee, complainant in equity, has a right to follow each infringement separately, which is a question hereafter discussed; and second, that the sale of a patented device is comparable to the sale of a chattel belonging to the patentee.

The latter proposition opens up the vexed question of the exact nature of the property evidenced by letters patent, and without undertaking to discuss the question at large, it is enough to point out, in answer to Judge Wheeler's argument, that the patent certainly does not purport to give title to the concrete article claimed, but only a temporary monopoly of making, using and selling it.

For example, if one acquires by purchase an infringing article, the mere possession of the article by the vendee is not of itself an infringement of the patent; in such case the vendee owns the infringing article for some purposes, and may exercise many acts of ownership and control over it, even to the point of destroying it, but until he uses it or sells it he does not interfere with any right of property belonging to the patentee; and if the vendee chooses to lay the infringing article aside until the patent expires, he then owns it for all purposes.*

This is enough to show that the property evidenced by a patent is not the legal title to, or the right of possession of any infringing article.

* There are authorities for the proposition that the chancellor may order the defendant to deliver up the infringing machine to be destroyed or to be purchased by the patentee at the cost of materials; but this is a matter of discretion with the Court and not matter of right with the patentee-see Needham $v$. Oxiey, 8 Law Times 604 ; - and it proceeds, no doubt, on the theory that equity having power to enjoin the infringement, will, in a suitable case, insure obedience to the injunction by making a continuance of the infringement impossible. 
It follows that the patentee could not maintain an action of replevin to recover infringing articles (honestly acquired) from one who was using them in violation of the patent. By parity of reasoning, he could not maintain trover for the conversion of the chattel against one who sold the infringing article; but could only recover damages as in trespass for the unlawful acts of use or sale done by the infringer.

This may be made clearer by a recollection of the fact that the manufacture and sale of an article by an infringer does not deprive the patentee of any concrete thing, or take away anything from him. It may lose him the sale of an article which he would otherwise have sold, but that loss is an incident of a special situation in trade and not a necessary result of the infringement.

In other words it is true, both in law and in fact, that the sale of a patented article is not, as Judge Wheeler assumes, like the conversion of a chattel belonging to the patentee,_but is a naked infraction of the exclusive right to sell the patented article, which may or may not actually damage the patentee. thing.

It is a tort, but not a conversion or witholding of any concrete

The distinction is a nice one, and it is the more difficult to make because courts are continually drawing analogies in its explanation which serve the particular purpose well enough, but remain to confuse and mislead the next comer. Root $v$. Railway, cleared up and swept away a mass of phrases in which the defendant had been styled a "trustee," and although the Supreme Court has not yet had occasion to perform, for the benefit of the profession, a like task in defining the exact character of the property granted by a patent, it is at least evident that the grant is of some kind of an incorporeal right, and not of title to any concrete thing.

It may therefore be affirmed with reasonable certainty that an infringer is not a trustee, and that he is not chargeable with the consequences of wrongfully converting to his own use the concrete infringing articles which he sells.

Upon what theory, then, is the infringer made to account for profits in a proceeding in equity?

It cannot be that equity will for any purpose convert a simple tort feasor into a trustee, and charge him with obligations which it is admitted that he has not assumed. Neither is there any reason for so doing, for the plaintiff's proper and legally sufficient pecuniary remedy for the tort is damages; and a court of equity 
will not establish a harsher rule for one class of tort feasors than another. Although, as stated in Root $v$. Railway, a court of equity, having once taken jurisdiction for another purpose, may apply the rule by which it compels trustees to disgorge the fruits of their unlawful use of trust property, it must in common justice apply the rule with reference to the fact that in the case of an infringer there has been no betrayal of a trust, and that there is in fact no trust fund. The theory of Root $v$. Railway is in fact too subtle and too easily misunderstood, and Mr. Justice Swayne, in the Goodyear case, seems to have stated the only tenable ground for holding the infringer to account, when he put it on the broad equitable principle that "the controlling consideration is that he shall not profit by his own wrong."

This relieves the case of any necessity for pretending that the defendant is a trustee when in fact he is not, or for assuming the illogical position that, though the plaintiff has no title to the property sold, he has title to the proceeds of the sale. It treats the profits as legally belonging to the defendants, but takes them from the defendant on the well-recognized principle that no man shall profit by his wrong, and gives them to the defendant in lieu of damages, on the equally well-recognized principle of preventing a multiplicity of suits. ${ }^{*}$

If this view be as correct as it seems reasonable, it does away with all fine-spun distinctions between actual and quasi trustees, and fixes the status of an infringer accounting in equity consistently as that of a simple tort feasor, who has fallen into the hands of equity collaterally.

It also resolves the conflict of authority between the Goodyear case and the Valve case in favor of the older doctrine; for if the defendant be simply a tort feasor, and his gains are to be taken from him simply that he may not profit by the tort, then he is clearly entitled in equity to the ordinary application of the rule of equitable set-off, in ascertaining the existence and extent of his gains.

As Mr. Justice Swayne puts it :

"The calculation is to be made as a manufacturer calculates the profits of his business."

* The statute, it is true, has of late years given authority to courts of equity to assess damages directly in patent causes, but this fact does not alter the theory upon which the same courts still exercise their original equitable jurisdiction in compelling the infringer to account. 
It still remains, in order to remove a remaining uncertainty, to inquire whether the complainant in equity may not nevertheless treat each separate infringement as a separate tort, and colleet damages, or defendant's profits in lieu of damages, on each separate tort as a separate cause of action.

The answer to this suggestion is two-fold: that there is but one cause of action stated in the bill, and not a number of separate causes of action ; and that, although each infringing act is technically a separate tort, the complainant has elected, for the sake of obtaining an injunction, to aggregate all the defendant's torts in one proceeding.

Having done this, he cannot take out of the hands of equity the adjustment of any one specific tort. This was expressly decided in Morss $v$. Knapp, 45 Fed. Rep. 199, where an injunction was issued restraining a complainant in equity from bringing a suit at law against the defendant for infringements of the patent, committed after the filing of the interlocutory degree, but before the coming in of the Master's report. And this case proceeded on the recognized principle that a plaintiff in equity is bound to submit to equity each and every controversy with the defendant of which the court can take jurisdiction under the original bill.

It seems, therefore, that the complainant should have no right to interfere between the court and the defendant to say what items the Master should take into the account in ascertaining the existence and extent of defendant's profits.

Judge Shepley thought that the right of the defendant to set off losses in reduction of profits was unjust to the complainant; but this presupposes that the complainant has some equitable right of property in the defendant's profits, which, (if Root $v$. Railway be good authority,) is as untrue in law as it seems to be in logic.

Literally speaking, the complainant, in common with other injured parties, is entitled to his actual damages and nothing more, and in the contemplation of equity, which awards the defendant's profits, in lieu of damages, these profits are presumably not intended to be greater than the actual damages, instead of which they are given. Moreover, under the present statute actual damages may be awarded in excess of defendant's profits.

The complainant in equity has, therefore, two measures of damages, between which he may elect; the ordinary and legally sufficient measure of actual loss, which compensates him for the 
injury sustained from the defendant's tort, and the extraordinary equitable measure of the defendant's profits, which do not belong to the complainant because they are profits, but are given to him under an equitable fiction as damages, and are also intended simply to compensate for the injury actually sustained from the defendant's tort, and are not given with any view of punishing the defendant.

If the defendant's profits, when ascertained, exceed the actual damage which the complainant has in fact suffered from the infringement, he is more than compensated. If the defendant's profits, when ascertained, fall below the actual damages sustained, the complainant is at liberty to prove and collect the amount of actual damage in excess of the defendant's profits.

In either event he is at least compensated for his actual injury as fully as the law intends to compensate an injured party ; and it is therefore no injustice to allow the defendant to reduce his profit by setting off bad debts and other unprofitable sales, because the complainant still retains the ordinary right to recover his actual damages.

It will be suggested that equity intends to give more ample compensation than the rule of legal damage affords; but that is ordinarily the result of the jurisdictional fact of a betrayal of trust or confidence, or of a special inadequacy of the legal remedy.

In ordinary patent causes the sole inadequacy of the law is cured by the issue of the injunction, after which, in the strictness of chancery practice, the patentee would then be remitted to his action at law for damage; and the fact that equity retains the cause to prevent a multiplicity of suits is not a jurisdictional fact which justifies any greater tenderness to the patentee or any greater hardship to the infringer than either would receive at the hands of a court of law.

The equitable rule that no man shall profit by his wrong is fully satisfied by ascertaining the real profit " as a manufacturer calculates the profits of the business"; and the contrary doctrine of the Valve case can only be upheld on the apparently erroneous assumption that whenever any profit, however temporary, appears, it belongs of right and because it is a "profit" to the patentee.

As the court said in Root $v$. Railway, in commenting on the claim that the infringer was a trustee for the patentee in respect to profits :

" That would be a reductio ad absurdum, and, if accepted, would extend the jurisdiction of equity to every case of tort, where the wrong-doer received a pecuniary profit from his wrong." 
In conclusion, it may be said that as the property in patent rights is sui generis, the attempt to apply the ordinary rules of law and equity is necessarily difficult. It is certain that at present the whole subject of recovery for infringement is in an unsatisfactory condition, and that some other rule of compensation than that of recovering damages in the guise of defendant's profits ought to be adopted.

For instance, if the patentee has not gone into the market at all, he may nevertheless recover large profits from an infringer who has been at the risk of building up his business and has done it so successfully as actually to benefit the patentee by creating a market for the patented article. On the other hand, from another infringer, whose business has been unprofitable, the same patentee may collect nothing. Thus, though the tort is the same, and the actual damage nil, the patentee collects profits which may have been wholly due to a superior business capacity on the part of the one infringer, while the other goes free, simply because he is less intelligent.

The equitable rule that no one shall profit by his own wrong fails in patent causes to do substantial justice to a defendant, because success in trade depends more on the personality of the tradesman than on the goods in which he deals; and from another standpoint it seems clear that if the patentee is to receive compensation for the defendant's use of the invention, irrespective of actual damages, his title to such compensation ought to be based on some calculation of the value of the invention, and not to depend on the good or bad fortune of the defendant who uses it.

This rule has often been followed in cases where the patentee has himself put a value on his invention by exacting a uniform royalty or license fee for its use ; and it ought not to be impossible for a court of equity to ascertain from suitable proofs what would be a fair royalty for the use of the invention in controversy, and thus to apply a measure of damage which would be compensatory to the complainant as against all defendants, and which at the same time might allow a defendant who had realized an extraordinary profit by the exercise of uncommon business skill to retain a portion of the fruits of his sagacity.

This suggestion is perhaps wide of the mark at which this paper is aimed, and for the pyesent it is more essential that existing rules should be made consistent, than that new ones should be suggested. 